Financing: Inexistente

Conflict of interests: Inexistente

References

1. Marsden CD. Blepharospasm-oromandibular dystonia syndrome (Brueghel's syndrome). A variant of adult-onset torsion dystonia? J Neurol Neurosurg Psychiatry. 1976;39(12):1204-9.

2. Trugman JM, Leadbetter R, Zalis ME, Burgdorf RO, Wooten GF. Treatment of severe axial tardive dystonia with clozapine: case report and hypothesis. Mov Disord. 1994;9(4):441-6.

3. Adityanjee, Aderibigbe YA, Jampala VC, Mathews T. The current status of tardive dystonia. Biol Psychiatry. 1999;45(6):715-30.

4. Burke RE, Fahn S, Gold AP. Delayed-onset dystonia in patients with "static" encephalopathy. J Neurol Neurosurg Psychiatry. 1980;43(9): 789-97.

5. Lieberman JA, Saltz BL, Johns CA, Pollack S, Borenstein M, Kane J. The effects of clozapine on tardive dyskinesia. $\mathrm{Br} J$ Psychiatry. 1991;158:503-10

6. Tarsy D, Kaufman D, Sethi KD, Rivner MH, Molho E, Factor S. An open-label study of botulinum toxin A for treatment of tardive dystonia. Clin Neuropharmacol. 1997;20(1):90-3.

\section{Obsessive-compulsive symptoms in non-active rheumatic fever}

\section{Sintomas obsessivo-compulsivos em febre} reumática inativa

\section{Dear Editor,}

Rheumatic fever (RF) is an autoimmune disorder that follows infection by specific strains of $\beta$-hemolytic streptococci. ${ }^{1}$ Obsessive-compulsive symptoms (OCS) were first described in Sydenham's chorea (SC), the late central nervous system (CNS) expression of RF. In the last 10 years, consistent reports have found higher frequencies of obsessive-compulsive disorder (OCD), OCS and tic disorders (TD) in prepubertal RF children with ${ }^{1}$ and without ${ }^{2-3}$ SC. Swedo and colleagues called these neuropsychiatric disorders subgroup by the acronym PANDAS, ${ }^{3}$ whose validity as an independent entity has been largely discussed. The association between RF and OCD spectrum symptoms has been well documented in the active phase of $\mathrm{RF}^{2-3}$ and has been hypothetically attributed to antibodies directed against invading bacteria that cross-react with basal ganglia structures. ${ }^{3}$ Therefore, we decided to further explore the relationship of RF and OCD spectrum symptoms in patients in the non-active phase of RF.

A descriptive study performed in an academic Brazilian hospital - Oswaldo Cruz Hospital (Recife-PE) - included 50 consecutive adult patients from the outpatient clinic for valve heart disease, who have had at least one acute RF episode in the past. Exclusion criteria were, age under 18 and over 45 years and/or the presence of neurological disorders or other heart diseases of non-rheumatic etiology. Written informed consent was obtained. The RF diagnosis was established according to modified Jones criteria. ${ }^{1}$ Psychiatric symptoms were assessed by SCID-IV and diagnosis of OCS was made when patients met criteria only for obsessions or compulsions. ${ }^{4}$ Best Estimate Diagnosis ${ }^{4}$ was made with two senior psychiatrists (ECM; KP). Our sample comprised 14 men and 36 women with a mean age of 34.5 years $(S D=9.8)$. We found OCS as the most frequently reported psychiatric symptom occurring in 16 patients (32\%). Agoraphobia was reported in 1 individual (2\%), generalized anxiety disorder in 5 (10\%) and major depressive disorder in 14 (28\%). Only 1 individual $(2 \%)$ presented OCD in its complete form. The OCS was not related to the number of lifetime RF exacerbation episodes ( $p=0.16)$ or previous cardiac surgery $(p=0.37$ ).

We recently reported the presence of OCD, TD and body dysmorphic disorder in another sample of non-active RF. ${ }^{2}$ Furthermore, in a recent controlled study performed in another academic hospital - InCor HCFMUSP (Sao PauloSP) - assessing 97 heart disease outpatient subjects we found increased frequencies of OCS in non-active RF compared to controls $(p=.02) .^{5}$

Thus, we have systematically found OCD spectrum symptoms in different samples of RF patients in the nonactive phase, which is theoretically interesting and intriguing, as chronic sequels that continue to develop long after the initial RF episode have been described concerning joints, cardiac tissue, and the $\mathrm{CNS}^{1-2,5}$ in the form of chorea. However, it is possible that RF acute changes could have persisted or triggered other immunologic responses. The low prevalence of full OCD and the absence of a control group are important limitations of these studies. Further neuroimmunological and genetic studies are needed to elucidate the mechanisms through which active and non-active RF confers a high risk for these neuropsychiatric symptoms.

\section{Pedro G Alvarenga, Ana C Floresi, Ana G Hounie Universidade de São Paulo (USP), São Paulo (SP), Brazil Kátia Petribú, Milena F França Faculty of Medical Sciences, Universidade de Pernambuco (UPE), Recife (PE), Brazil}

Department of Psychiatry, Institute of Psychiatry (IPq), Clinical Hospital, Medical School, Universidade de São Paulo (USP), São Paulo (SP), Brazil

Financing: None

Conflict of interests: None

\section{References}

1. Dajani AS, Ayoub E, Bierman FZ, Bisno AL, Deny FW, Durack DT, et al. Guidelines for the diagnosis of rheumatic fever: Jones criteria, updated 1992. Circulation. 1993;87:302-7.

2. Hounie AG, Pauls DL, Mercadante MT, Rosario-Campos MC, Shavitt RG, de Mathis MA, de Alvarenga PG, Curi M, Miguel EC. Obsessivecompulsive spectrum disorders in rheumatic fever with and without Sydenham's chorea. J Clin Psychiatry. 2004;65(7):994-9.

3. Swedo SE. Pediatric autoimmune neuropsychiatric disorders associated with streptococcal infections (PANDAS). Mol Psychiatry. 2002; 7(Suppl2):S24-5

4. Pauls DL, Alsobrook JP 2nd, Goodman W, Rasmussen S, Leckman JF. A family study of obsessive-compulsive disorder. Am J Psychiatry. 1995:152(1):76-84.

5. Alvarenga PG, Hounie AG, Mercadante MT, Diniz JB, Spina G, Salem $\mathrm{M}$, et al. Obsessive-compulsive symptoms in adults with history of rheumatic fever. J Neuropsychiatry Clin Neurosci. (in press). Submetido em 21/10/2004 e aceito em 26/7/2005. 